\title{
THE INFLUENCE OF COVID-19 ON INTERNATIONAL LABOR MIGRATIONS FROM BOSNIA AND HERZEGOVINA TO EU
}

Izvirni znanstveni članek COBISS 1.01

DOI: $10.4312 /$ dela.53.71-95

\section{Abstract}

The article deals with the contemporary labor migrations from Bosnia and Herzegovina to Slovenia and the other countries of European Union, specifically during the period of the COVID-19 pandemic. On the basis of fieldwork among the participants in these migrations, it seeks to identify the specifics of circumstances and situations that arose suddenly with the closure of political borders and the demands of social distancing. In these circumstances, we supposed that labor migrants found themselves to be a particularly vulnerable group of population. The case study has denied that this is completely true. On the other hand, labor migrations from Bosnia and Herzegovina to Central, Western and North European and some non-European countries have been a continuous process for the last century and at least migration flows must be taken as a fact which directions, volumes and character are greatly influenced by labor market regulations in each individual EU member and other states. Periodically, specific political and social situations also gain importance. The COVID-19 pandemic has exactly such an impact.

Keywords: labor migrations, Slovenia, EU, Bosnia and Herzegovina, COVID-19

${ }^{\star}$ Faculty of Arts, University of Maribor, Koroška cesta 160, SI-2000 Maribor

${ }^{* *}$ Obala 144, Lucija, SI-6320 Portorož

${ }^{* * \star}$ Department of Geography, Faculty of Arts, University of Ljubljana, Aškerčeva 2, SI-1000 Ljubljana, Slovenia

e-pošta: bojan.cudic@um.si,matjaz.klemencic@um.si,jernej.zupancic@ff.uni-lj.si 


\section{VPLIV COVID-19 NA MEDNARODNE DELOVNE MIGRACIJE IZ BOSNE IN HERCEGOVINE V EU}

\section{Izvleček}

Prispevek obravnava vprašanje sodobnih delovnih migracij iz Bosne in Hercegovine v Slovenijo in druge države Evropske unije, in sicer specifično za čas pandemije COVID-19. Na podlagi terenskega dela med migranti skuša opredeliti posebnosti okoliščin in situacij, ki so nastale nenadno z zapiranjem političnih meja in zahtevami družbenega distanciranja. Predvidevali smo, da so se delovni migranti v teh okoliščinah znašli kot posebej ranljiva skupina prebivalstva. S študijo primera smo dokazali, da to ne drži povsem. Po drugi strani pa so delovne migracije iz Bosne in Hercegovine proti državam Srednje, Zahodne in Severne Evrope kontinuiran proces zadnjega stoletja in je vsaj selitvene tokove treba vzeti kot določeno družbeno konstanto, na katere smer, številčnost in značaj $\mathrm{v}$ veliki meri vplivajo ureditve trga dela $\mathrm{v}$ posameznih članicah EU, obdobno pa dobijo prevladujoč vpliv tudi specifične družbene razmere. Tak vpliv predstavlja tudi pandemija COVID-19.

Ključne besede: delovne migracije, Slovenija, EU, Bosna in Hercegovina, COVID-19

\section{INTRODUCTION}

The onset of the COVID-19 pandemic in the early months of 2020 (Shrivastava S., Shrivastava P., 2020) also had a profound effect on migration flows. In order to curb the spread of this new and apparently highly contagious disease, countries introduced one after another a series of measures that can be grouped together under the common notions of social distancing and hygiene measures. Temporary restrictions on movement virtually interrupted the established migratory flows for work, education, and tourism. The article pays special attention to the field of temporary guest labor migration between Bosnia and Herzegovina (BiH) and EU countries, especially Central Europe. Based on a qualitative analysis of interviews conducted in April 2020, information was obtained on the circumstances, course and specific problems for migrants along the path of otherwise normal migratory flow, in the source of migrants i.e. Bosnia and Herzegovina and in the target areas of these migrations. We examined in detail the measures that directly and indirectly affected the described work relocations and identified the adjustments of the participating migrants in specific circumstances for migrants.

Why BiH? The country belongs to one of the most migratory intensive countries in Europe. The motives and reasons as well as circumstances were different, but during the last century the emigration flows were constant. For Slovenia, the immigration from $\mathrm{BiH}$ is clearly the largest one; the $\mathrm{BiH}$ `s diaspora represents an important part of 
Slovene society. In the past year (2019), the number of issued residence permits for citizens of $\mathrm{BiH}$ was the largest among all issued permits. According to the Eurostat data, it was issued 56,355 first permits for BiH's citizens just in 2019 (Eurostat, 2020). BiH is geographically close to Slovenia and both countries share a common past during the so-called Yugoslav period (and also before); that all stimulates migration flows.

The research focused mainly on the effects of specific circumstances triggered by the rather sudden onset of the COVID-19 pandemic on labor migrants. We assumed that labor migrants from $\mathrm{BiH}$ were a more vulnerable group of workers for job loss due to the measures of the governments of the countries in which they worked. However, the effects of a pandemic cannot be considered outside the context of other migratory flows from the country under study. That's why we paid some attention to the historical background of migrations from $\mathrm{BiH}$ during the modern period.

The article is divided into three parts: an introductory part with explanations, an outline of migration traditions and practices between Bosnia and Herzegovina and Central Europe, and an empirical part with a presentation of field qualitative analysis. The introductory part presents the main premises of migration in the geographical area between $\mathrm{BiH}$ as the source of migrants and target areas in Central European countries and more broadly in the EU. The methods of work and data collection in the field are described in more detail, as well as the presentation of the sources for statistical and other data and, also, the methods of collection of relevant documents. The second part presents an in-depth analysis of past migration flows, the circumstances in which individual migrations took place and the consequences that these migrations have left on the $\mathrm{BiH}$ as a source as well as transitional and target areas. This historical-geographical outline explains temporary or permanent migration as a typical and fairly constant way for the population of $\mathrm{BiH}$ to respond to various challenges in their country. Labor migrations represent a certain social durable phenomenon which resulted in perceptions of inhabitants of $\mathrm{BiH}$ about the advantages of emigration to achieve personal socio-economic goals. The third - empirical part - is the analysis of migration related events during the period of declared pandemics and measures of social distancing and analysis of the course and consequences of it on migration flows. The concluding part follows the conclusions regarding migration policy in the specific social conditions that arose during the pandemic. This is also important because it is likely that Europe will face similar challenges in the future.

\section{METHODOLOGY OF RESEARCH AND SOURCES}

Research of international (especially labor) migrations is a demanding task. Due to the nature of these migrations, which are often not accurately (or not at all) officially recorded, and are also not accurately identifiable in some cases of periodic assessment due to the seasonal nature, it is necessary to rely on various estimates and information 
obtained directly in the field and from the media. As far as figures are concerned, certain derogations and only indicative estimates must be accepted. Surveys or targeted interviews, on the other hand, bring the latest trends and a range of information about the nature and various processes and problems associated with these flows. Shortly after the onset of the COVID-19 epidemic/pandemic in Europe, limited field data collection and information collection was practically the only way to focus the effects of labor migration and related issues in the areas of emigration, transitional and target areas. We use terms like labor migration (migrants) as well as working migrants (and migration when thinking about the phenomenon or a process), because the "work" is a predominant motive or reason for movements of individuals across international (political) borders. Taking a longer period into account, many "seasonal" or temporary migrations became permanent due to various reasons and / or circumstances. The consequences are diasporas, established in almost all countries of Western, Northern and Central Europe and other countries of the world. This process is known for Slovenes too, despite the fact that Slovenia became a neto-immigrant country during last decades of 20th century (Ilc Klun, 2014).

Fieldwork included conducting targeted interviews with migrant workers who took part in return flows due to the declaration of the COVID-19 pandemic in the countries where they worked, and subsequent return to these countries when the circumstances allowed. In this way, we only got a homogeneous social group in terms of status and circumstances. However, it was much more diverse in terms of structure (age, gender, education, and position in the profession or in the work they performed).

The structure of the interviews was planned because we wanted to find out the experiences of migrants and the problems they had to cope with by current job losses and return problems along with legal and administrative procedures and especially social and economic consequences due to loss of income and return to work. Only indirectly were we able to identify the authentic problems of employers who found themselves without workers and had to, at least some of them, in some way compensate for this due to the nature of their field of economic activities. However, the focus was mainly on migrants and their specific problems. Considering the short time and very changing circumstances in this area (it was not known how long the epidemic, which required mainly different measures of social distancing, could last), the rapid preparation of the interviews and their implementation was very important.

The survey was conducted in April 2020. Twenty-two interviews took place all in the north-west part of the country and surrounding areas in Republika Srpska entity. Among twenty-two migrants interviewed they originated from different cities i.e: Banja Luka (7), Derventa (5), Glamoč (3), Bosanski Petrovac (3) Prnjavor (2), Drvar (1) and Brod (1). By gender structure twelve were men and ten were women. By age structure three workers interviewed were younger than 25 years, seventeen were between 25 and 40 and three were between 41 and 60 . 
By the level of education, the survey included relatively well educated and skilled migrants: 13 or a good half of respondents had higher or university education, 5 were well qualified and experienced workers, while 4 were unskilled workers with primary level of education. The respondents work or worked in institutions or companies in the following sectors: transport, industry, education, IT, construction, catering, sales and health. According to the results of this field research, single people and people who had a family with children from $\mathrm{BiH}$ decided to work in EU countries. Among the respondents, there were seven workers living alone, six living with a partner, while nine had a family with children.

In the survey the respondents answered questions related to work in the EU, and the research was partly related to the emergence of coronavirus and the consequences of the pandemic in the field of international employment and the flow of people and work. The sample was small, so that any quantitative approach might be questionable. The interview was semi-structured. We turned to qualitative approach, using migrants' life experiences in the context of corona pandemic, as mentioned before (as well below). Due to personal contact when interviewing, we estimate that the respondents answered correctly and that we can trust the gained information.

In doing so, we also had to critically consider the significant role of strong emotions by which the interviewees were overwhelmed. Since people we interviewed lost their work and income, and had difficulties in crossing borders, we expected greater criticism of their own situations because of the response of various institutions. They had to face a number of disadvantages which came with the establishment of mandatory distancing measures and in some cases quarantine. They also had to confront the absence of systematic care for returnees by home countries as well as with unwelcoming reception in the home country. Therefore, we tried to consider situations, but to take subjective opinions and experiences with some reservations. However, the subjectivity of responses in studying the life experiences of migrants as a specific and often vulnerable group of the population is a common and by no means exceptional case. Probably the most appropriate method to explain the situations of migrants is the qualitative analysis. Interviews with carefully planned sample of respondents (who are / were directly involved into labour migration movements) is the base, also for the analysis by biographic-narrative method. The use of biographical-narrative method is not very common in geographical research, but in some regards demonstrate clear advantages. International migrations are exactly that field of research, where this method might be used (Ilc Klun, 2017). We simply must count on these methods. We believe, however, that we were able to obtain a realistic picture of the circumstances and situations that arose from the vast majority of respondents, which individual respondents personally took dramatically.

Another source of information was mainly news obtained from the media reporting what was happening during the "corona time": this phrase was quickly adopted for a specific short period of the declared epidemic COVID-19 and can be used as a 
technical term. As circumstances changed rapidly, the media were the main source of information for the population and at the same time also for reactions and reflections. News about the spread of the epidemic and, above all, various measures was introduced by the media, but could also be checked on the websites of various state services. In these cases, the information was mainly summarized to describe the circumstances and the wider developments.

The third essential source of data are statistical censuses and estimates of migration from Bosnia and Herzegovina as a source area of emigrants. While considering some older migration flows, we focused on the migration dynamics after 1960. The year is not a precise turning point in the history of migration of the described area, but it well marks the initial period of changed economic conditions in the Yugoslav federation, which began with rapid and planned industrialization largely also in Bosnia and Herzegovina, but only in selected areas which were rich in raw materials and energy resources. However, the very rapid planned development of the beginning of the industrial paradigm apparently also accelerated internal migratory flows, which were partly directed towards domestic industrial areas. Statistical censuses conducted every ten years show a sharp increase in the population employed in industry, mining, and services, as well as an intensive displacement outside $\mathrm{BiH}$. The opening of the labor market to "immigrants", who as "guest workers" became part of international migration flows from Southern Europe to the north resulted in large flows directed towards Central, Northern and Western Europe. We have shown in more detail the migrations to Slovenia, which in the Yugoslav period (until 1991) were the subject of internal inter-republican migrations, but with the disintegration of Yugoslavia they became emigrants as a demographic category due to political changes. During the decade of the Yugoslav wars of succession migrations due to crisis situations (refugees) took over the predominant character. For this period, various estimates are much more useful, summarized from the literature and only partially from statistical censuses. Later, after the stabilization of the situation and in the first decade of the $3^{\text {rd }}$ millennium also the relative economic success of Slovenia, economic migrants, both permanent and temporary, again became the predominant category of migratory flows in this wider area. Due to the weakness of statistical censuses in the region of origin, data from different registers in the target countries, which record labor migration accurately due to immigration quotas and work permits issued in the EU labor market, are much more useful. After 2004 (major enlargement of the EU), various forms of cross-border daily, weekly, and seasonal employment also began to increase, but this is not always recorded in the context of regulated labor migration. At the same time, the group we were studying was not among the most vulnerable groups, because most of the members were either well educated or were needed in the special situations that followed the epidemic. 


\section{HISTORICAL CONTEXTS OF EMIGRATION FROM BIH}

The historical framework of migration(s) from $\mathrm{BiH}$ as a typical long-term emigration country and the formation of relatively large diaspora from $\mathrm{BiH}$ in European and non-European countries is necessary to address if we want to satisfactorily explain current trends in migration flows from Bosnia and Herzegovina. Historical circumstances created the circumstances and conditions of migration, determined their abundance, character and direction. In addition to political changes, wars and conflicts, economic changes in $\mathrm{BiH}$ were important as reasons for emigration. In addition to material conditions, information, legal and political circumstances, and the formation of a mind set on migration were also important as the most appropriate form of resolving socio-economic issues in $\mathrm{BiH}$. It is the formation of a certain "tradition" of migration in one and diasporas in different European environments that, regardless of how these diasporas came into being, has significantly stimulated migration flows - and still does. Existing immigrant communities provide information to both parties - both potential migrants and the reception environment, and at the same time act as an attractive core for the chain migration.

Due to limited space, the historical framework is shown very briefly and only in the main phases. It is divided into two periods: the older and longer period of the formation of $\mathrm{BiH}$ in the current territorial framework to an independent state and the timeframe of an independent state from the end of the civil war in 1995 to the present day. In fact, this represents the Dayton structure of $\mathrm{BiH}$ and its position in the Balkan neighbourhood and wider in Europe. This refers mainly to the fact that Bosnia and Herzegovina is one of the few non-integrated European countries and a country under international supervision. In addition to the legacy of the last war, this creates a mix of circumstances due to which citizens' trust in the state administration is low and at least somewhat accelerates thinking that employment abroad is the most appropriate form of social prosperity.

\subsection{The migrations from Bosnia and Herzegovina during older modern period}

The current territorial framework of Bosnia and Herzegovina is a legacy of the rivalry between the Ottoman and Habsburg Empires and was finally formed in the $19^{\text {th }}$ century. Later, only minor territorial changes followed. The complex processes of ethnic identification have gradually formed three ethnic communities, of which the current Bosniaks are the most numerous, but the youngest community in terms of the process of final formation. Serbs and Croats have their ethnic and political cores in neighboring countries. However, in $\mathrm{BiH}$ these groups enjoy a status of a constituent community and not a minority. The Serb community is organized mostly in the Republika Srpska entity, while Bosniaks and Croats mostly in the cantons of the federal sub-state - the Federation of Bosnia and Herzegovina. 
Bosnia and Herzegovina is historically a land from which many waves of emigrants left. People settled in $\mathrm{BiH}$ in quite large numbers during its Habsburg period after occupation in 1878 and annexation in 1908 . We can prove this by reading the statistical data on mother tongue according to the census of 1910.

Table 1: Mother tongue of the internal immigrants from Austria-Hungary to Bosnia and Herzegovina in 1910.

\begin{tabular}{|l|r|}
\hline Mother tongue & Number of immigrants \\
\hline Slovene & 3,864 \\
\hline German & 23,183 \\
\hline Non-South Slavic & 27,044 \\
\hline Magyar & 5,795 \\
\hline Total & 59,886 \\
\hline
\end{tabular}

Source: Winkler 1931, pp. 212-213.

Most of these people served as officials and soldiers for the Habsburg state. The territory of $\mathrm{BiH}$ formed the XV corps of the Austro-Hungarian Common Army (Hazemali, 2017, p. 172). There were also some immigrants with specific skills like miners and entrepreneurs (Winkler, 1931, pp. 212-213). There were 1,989,929 people living in $\mathrm{BiH}$ in 1910, 1,931,802 in 1921, and 2,316,000 in 1931 (Klemenčič, Žagar, 2004, p. 110). Of course, World War II had negative impact on the population development, but in 1961 there were 3,278,000 people living in $\mathrm{BiH}$ due to high birth rates in particular of Muslim part of population. Twenty years later in spite of the negative migration balance of approximately 400.000 we can follow a significant increase of the number of inhabitants of $\mathrm{BiH}$ to 4,121,000 (Klemenčič, 2000, p. 152) The trend continued until the last Yugoslav census of 1991, when there were 4.377.033 residents in the country (Pašalič, Lalić, 2020, p. 13).

During the period of the second (socialist) Yugoslavia, Bosnia and Herzegovina was one of its federal republics. Due to its central location and the associated strategic security on one hand, and especially the abundant mineral and energy wealth on the other, the planned industrialization of the socialist type significantly changed the economic and social structure of Bosnian society. Within a few decades, large industrial centres were formed that employed domestic labor. By the end of the 1980s, society of $\mathrm{BiH}$ was already industrialized and had a significant industrial-technological infrastructure, as well as a relatively skilled population. However, at the same time, intensive emigration from Bosnia and Herzegovina to other developed regions of the Yugoslav federation developed. Slovenia was particularly attractive for immigration. Immigrants from $\mathrm{BiH}$ came to have the same jobs as in the environment of their own republic, but as a rule for much higher incomes. The same motive drove many into a fairly large flow of labor migration to Central, Western and Northern Europe (Bertić, 1987). These "guest workers" became a social constant and an anchor 
for new migration flows. A specific social subculture of "guest workers" was formed (Mežnarić, 1986). Despite the weaknesses of the lifestyles of these emigrants with the separation of families and the rift between the places of work and the home environment, the decades-long process shaped not only a large diaspora but also significantly structured receptive societies. Slovenia became an important anchorage for $\mathrm{BiH}$ emigration. They came from all three ethnic groups, which are also well represented in Slovenia (Verska, jezikovna in narodna sestava ..., 2003). Slovenia is thus faced with both trends: the characteristics of more than a century of emigration and the same time the characteristics of the immigrant society (Komac, 2007). In the context of our research, it is important that the established diasporas from $\mathrm{BiH}$ have in the future and to this day acted as attractive cores of new immigration, including labor migration.

Second challenge was a civil war in $\mathrm{BiH}$ after dissolution of Yugoslav federation. As a result of the war in Bosnia and Herzegovina in the first half of the 1990s more than 2 million refugees had to leave their homes (Pirjevec, 2003, pp. 451-454). According to the UN High Commissioner for Refugees and various government institutions most of the refugees had originally resettled within the borders of Bosnia and Herzegovina (1.2 million). Many settled in the successor states of the former Yugoslavia and in other European countries and outside Europe (Klemenčič, Žagar, 2004, p. 320). In Slovenia, there were approximately 75,000 refugees, and most of them became new citizens ( $\mathrm{Zu}$ pančič, 2004). Since that, the next migration follows two decades later, when Bosnia became a transitional country on a Balkan-route for transcontinental migrants, mainly from Asia (Rogelj, 2017). Some Bosnian citizens follow these migrants.

Table 2: Number of refugees from $\mathrm{BiH}$ in 1995 according to the countries of settlement.

\begin{tabular}{|l|r|}
\hline Country of immigration/refugees & Number of refugees \\
\hline Croatia & 453,000 \\
\hline Montenegro & 38,600 \\
\hline Macedonia & 28,000 \\
\hline Serbia & 405,000 \\
\hline Sweden & 50,000 \\
\hline Netherlands & 33,000 \\
\hline Turkey & 52,000 \\
\hline Saudi Arabia & 7,000 \\
\hline Libya & 3500 \\
\hline Total & $1,070,100$ \\
\hline
\end{tabular}

Source: Klemenčič, Žagar, 2004, p. 320. 
By 1996 approximately 20,000 Bosniaks/BiH’s Muslims were accepted as refugees in the United States. According to the data of the Office of Immigration Statistics of the Department of Homeland Security during the period 1996-2001, the United States accepted more than 123,000 refugees from Bosnia and Herzegovina who had lived as refugees in different European countries. According to some estimates the number of those who settled in the US from Bosnia and Herzegovina amounted to more than 230,000. The majority of Bosniaks settled in St. Louis, Missouri, which hosts the largest number of Bosniaks outside Europe, in New York, Chicago and some smaller US cities. Most of Serbian and Croatian refugees joined their friends and relatives in classic settlements of both ethnic groups i.e. Pittsburgh, Pennsylvania, Chicago and Joliet, Illinois (Klemenčič 2013, p. 770). The data from 2011 Canadian census show that 22.920 people stated that they were of Bosnian descent (Statistics Canada, 2020). The majority of BiH`s Canadians emigrated to Canada as refugees during and after the last war in $\mathrm{BiH}$.

\subsection{Recent migration trends from Bosnia and Herzegovina}

In spite of all peace agreements most refugees are still not able to return to their homes, or even they do not want to return to their homes. Consequences of the war, including the changed ethnic distribution, remnants of continuing ethnic intolerance, lack of economic security, and poor economic conditions were among the key reasons why refugees left regions in the Bosnia and Herzegovina. The refugees who left Mostar in Herzegovina have not been able or do not want to return to their homes. As a consequence of the very bad economic situation the masses of economic migrants continue to emigrate to join their relatives and friends in foreign countries. It is also interesting to note that, although many home places were destroyed during the last war, most of the houses were renewed by 2020 . We have to note however that people, who successfully integrated in their new social environment, found jobs and built new homes and accommodated into new life in Western European countries, USA, Canada or Australia. They do not want to return to their home country. This is common for all immigrants but especially for those whose standard of living in the countries of emigration is much lower than in the countries of immigration. Additional factor could be lack of economic security and prosperity. Both played a role in $\mathrm{BiH}$ as well as in the low rates of return to then Yugoslavia after World War I and World War II. (Klemenčič, 1987, p. 46). Also emigrants themselves still have habit of visiting their real estates, properties and relatives in $\mathrm{BiH}$, while their children and grandchildren are not so keen to come. Grandchildren do not come even once a year. They live their own life as they have acculturated or even assimilated in their new homelands, as observed by one of the authors (Ćudić).

It is interesting to note that a quarter of century after Dayton agreement was concluded a certain number of Muslims/Bosniaks and Croatians have come to live in 
Republika Srpska and Serbs migrated into Federation $\mathrm{BiH}$, because they have, due to enacted quotas and results of 1991 census priority for employment in public sector. Also, the reasons for emigration have changed comparing to the $19^{\text {th }}$ and $20^{\text {th }}$ century. The pull factors are better education system, health services and public support system in general in addition to the above-mentioned push factors. Using social media (Facebook, Instagram, Twitter) they are comparing quality of their life with their peers who live in developed countries of the Western World. Consequently, many people are leaving their comparatively well-paid jobs in $\mathrm{BiH}$ and together with their families move to different Central- and Western European countries, North Ameri$\mathrm{ca}$ and Australia. There are even examples of people leaving their businesses when leaving the country. To conclude: in the last 10 years the main issues which have led people to emigrate are the quality of living environment and search for prosperity and economic security. Before the pandemic of COVID-19 several hundred people even emigrated from $\mathrm{BiH}$ to China to study and work as they recognize it as a place where they would be able to find some kind of economic security (as observed by co-author Cudić). There they must be ready to live in even more diverse place than it is $\mathrm{BiH}$.

According to the official census data the number of inhabitants of Bosnia and Herzegovina between 1991 and 2013 decreased from 4,377,033 to 3,531,159, i.e. the net decrease was almost 20\%. This was a result of the wars of the first half of the 1990s as well as the economic crisis which followed. It is shown also in the percentage of the unemployed which according to the official data was $43.2 \%$. There was however a significant difference between the entity of Republika Srpska (37.3\%) and the entity of Federation $\mathrm{BiH}$ (45.9\%). Of course there are quite a few workers who participate in the so-called grey economy otherwise people would not be able to survive. The population also depends heavily on remittances of emigrants. $\mathrm{BiH}$ so represents quite a reservoir of potential emigrants (Pašalič, Lalič, 2020, p. 13).

One of the most significant indicators of the economic and political situation in a chosen country are the data on migration balances. Since 1991 those balances for Bosnia and Herzegovina as a whole and for all of the entities have been highly negative.

Table 3: Migration balances in Bosnia and Herzegovina during the period 1991-2019.

\begin{tabular}{|l|c|c|}
\hline Entity of BiH/territorial unit & $\begin{array}{l}\text { Migration balance } \\
\mathbf{1 9 9 1 - 2 0 1 9}\end{array}$ & $\begin{array}{c}\text { Migration balance } \\
\mathbf{2 0 1 5 - 2 0 1 9}\end{array}$ \\
\hline Republika Srpska & $-497,423$ & $-77,758$ \\
\hline Federation BiH & $-805,060$ & $-146,368$ \\
\hline Brčko District & $-14,525$ & $-4,594$ \\
\hline Total & $-1,317,008$ & $-223,720$ \\
\hline
\end{tabular}

Source: Pašalić, Lalić, 2020, p. 13. 
These are the consequences of war as well as bad economic situation after the war. It is worth noting that the trend continued also during the last five years as migration balance for $\mathrm{BiH}$ was highly negative.

These data show that the pace of emigration from $\mathrm{BiH}$ as a whole, and especially from the Federation $\mathrm{BiH}$ accelerated especially during the last five years when there was no war, but economic conditions worsened (Pašalič, Lalič 2020, p. 13). The result of all these developments is that the number of inhabitants of $\mathrm{BiH}$ in 2019 decreased to 3.069.025 (Pašalič, Lalić, 2020).

\section{CORONA VIRUS PANDEMIC AND WORKING MIGRATIONS FROM BOSNIA AND HERCEGOVINA: CASE STUDY}

According to our survey the coronavirus pandemic (COVID-19) in most cases has not endangered jobs and incomes of $\mathrm{BiH}$ workers working in the European Union (EU), although it has significantly affected their work, and mostly some low-skilled workers have lost their jobs.

Figure 1: BiH municipalities that are covered by the survey, $N=22$.

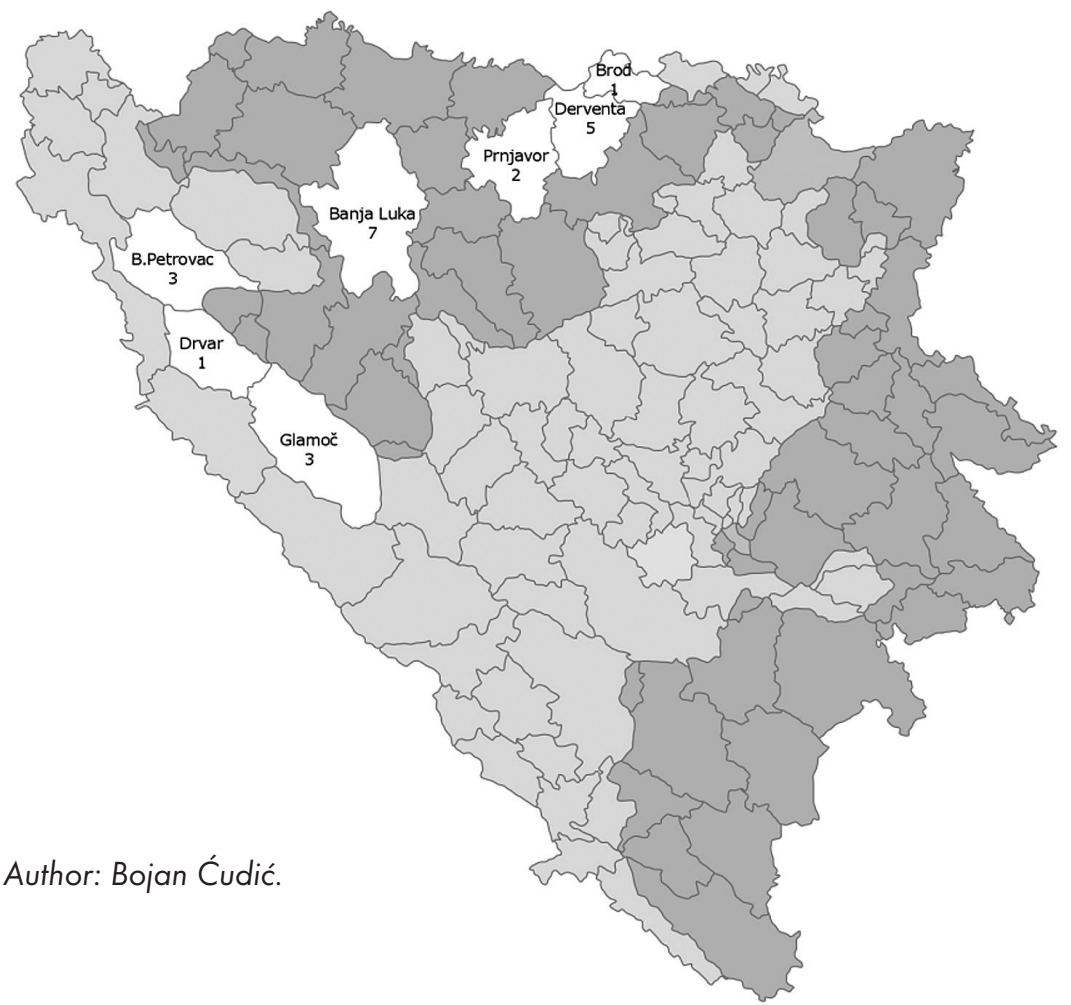


In regard to the current employment status, two respondents stated that they were unemployed, three had temporary, and as many as 16 respondents had a permanent employment.

The survey showed that workers of all ages, all levels of education and different occupations had the same opportunity for employment in EU countries, and that there were various ways to get a job in one of the countries of the EU.

When it comes to education, there were no respondents who completed only primary school, while one respondent stated that he had a vocational education, five completed a technical secondary school or grammar school, 13 had a university degree or college, and three stated that they had another type of education.

The respondents stated that they had worked or were working as: drivers (4 respondents), journalist / human resources administrator (1), researcher at a faculty (1), worker in catering and cleaning facilities (1), mechanical engineer - teacher in secondary school (1), worker in an electrical cabinet company (1), workers working in cleaning (3), worker in industry (1), educator and trade intermediary (1), mechanical engineer in the industrial sector 1), sales manager in industry (1), electrical engineer in industry (1) computer scientist (2), auxiliary worker in the machine industry (1), worker in the field of finance (2). The respondents found work through specialized websites with job offers or social networks and through relatives and acquaintances, and they got jobs by applying for job through an employment agency, based on a recommendation, or had already worked for a foreign company in $\mathrm{BiH}$ and they had been transferred to another job in one of the EU countries.

Regardless of their profession, some of the respondents had and used the opportunity to find another job in the EU, which means better pay and working conditions (low-skilled workers), or with higher pay and better working conditions and a possibility of promotion to a higher position or employment in the profession (highly qualified workers).

The respondents work or worked in Italy, Croatia, Slovenia, the Czech Republic, Austria, or Germany and have between 8 months and 14 years of work experience in one of the EU countries, as it is presented on map 2. 
Figure 2: European countries where respondents work, $N=22$.

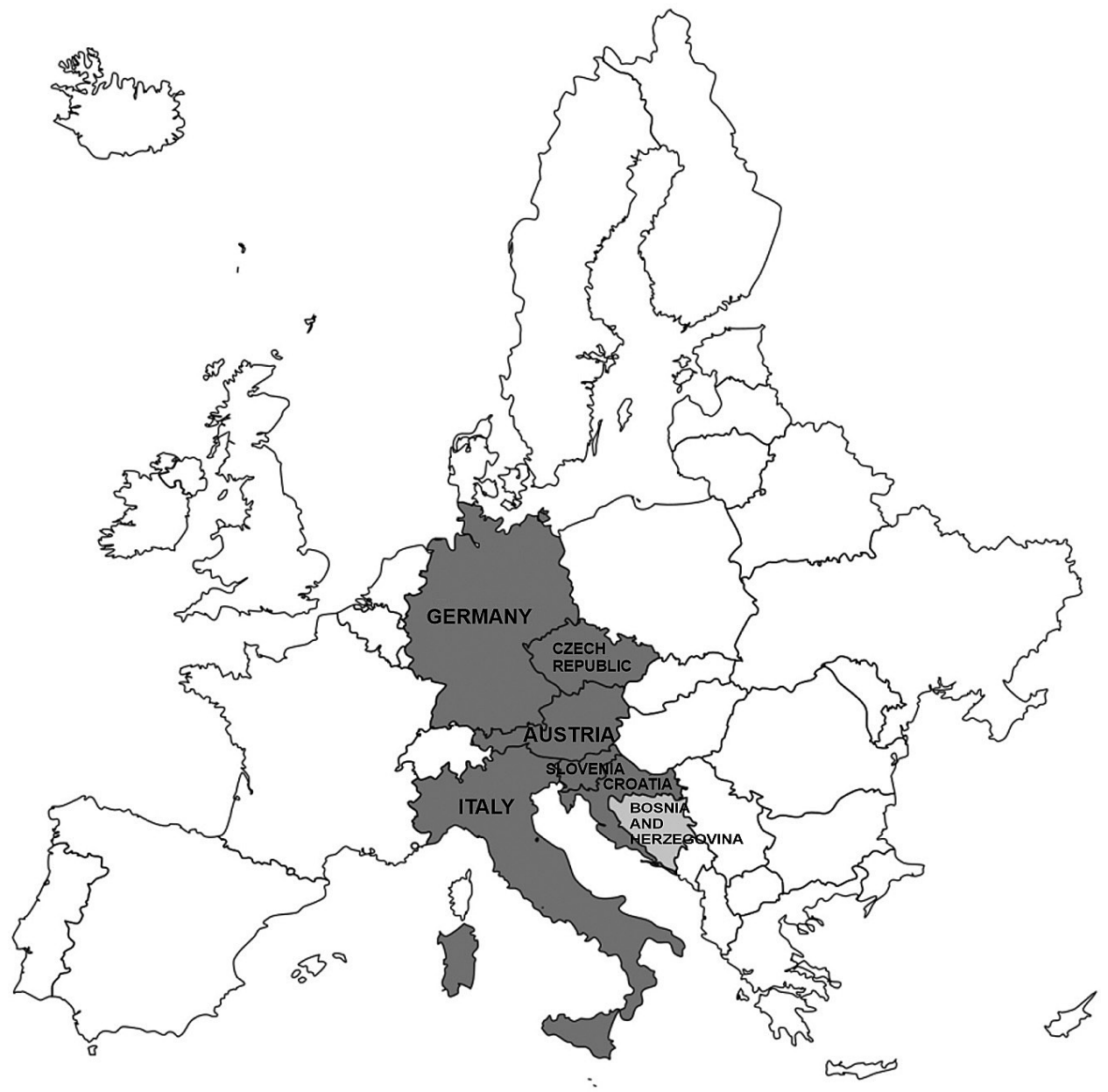

Author: Bojan Ćudić.

\subsection{Motives for migration}

Economic motives for migrating in search of better employment opportunities have been the common reason for most migrations for several decades apart from political crisis and war (Rančić, 1990). The phrase "better life" is thus a uniform synonym for an individual's decision to move to a chosen changed location. When it comes to choosing the country of immigration these are mainly the countries of Central, Western and Northern Europe. However, economic motives are just a kind of cloak or cover, diverse circumstances, conditions, information, resources and finally also perceptions 
of quality of life, which unfold in a more detailed analysis of individual stimulated individual to decide to move for work (Lazanin, 2017). The mentality of potential migrants in particular plays a very important role in this. The fact that emigration typically continues in the most emigration-intensive regions, even in cases where they have comparable employment nearby, suggests that other circumstances, especially the existence of an already established immigration core, make life easier for potential migrants. As many jobs are temporary, regular opportunities to communicate with the home environment are crucial. Material or economic motives should therefore be viewed in many ways and considering the migrant's personal and family situation (Peračković, Rihtar, 2016). This is what the respondents in our sample are basically stating in their answers. It is interesting to note that for most of them better salaries than in $\mathrm{BiH}$ are important, while at the same time also the opportunities for better working experiences, as well as the improvement of their professional skills and living in better organized social environment are important.

Even in the interviews the economic motive is clearly highlighted. However, the respondents later described it in more detail with other characteristics, among which the acquisition of experience and references, the acquisition of start-up capital for home activities, better working (including material, technical) conditions, organization and order and interpersonal relations. This motive also fits well with a convincing level of satisfaction with work and the working environment abroad, although they stated that they have to sacrifice a lot for this.

The sample consists of 22 respondents. When they answered the question how important work in the EU for them is, 18 of them answered that having a job in one of the countries of the European Union is important because they are provided with good earnings. The salaries are much better in $\mathrm{EU}$ than in $\mathrm{BiH}$. For four respondents, earnings are not a reason at all for deciding to work in one of the EU countries. For one, working in the EU is important primarily because he can live in an organized system. For three of them the employment in the EU gives them an opportunity to advancement and professional development. Three respondents stated that they would return to $\mathrm{BiH}$ as soon as they earned enough money. A researcher who works at a university in Slovenia pointed out that working there enabled him to earn a good salary, improve the quality of work, and make the contacts, that opened new business opportunities for him.

A respondent who worked first in Germany on maintenance and cleaning of facilities and then in catering in Italy, stated that working in the EU meant that she could live a normal life and had fulfilled certain desires, both for herself and her child. For a worker working on maintenance and cleaning of facilities in Austria, a job in the EU means a better future and financial security.

For a driver employed in Slovenia, this job is important in order to earn enough money to start a business in $\mathrm{BiH}$. His intention is to return there to fulfil his ambitions for which he needs another five to seven years. 
For a mechanical engineer who, after working in school and in a manufacturing company, got a job in a secondary school in Germany, a job in the EU is important to gain basic capital as well as acquaintances and experience to start his business in $\mathrm{BiH}$. He sees his current job and lifestyle as temporary. A driver, who works in Slovenia went there to earn and repay debts because he had a family business in $\mathrm{BiH}$ that is now in loans. When he repays the debts, he will surely return to $\mathrm{BiH}$ and continue to work in family business he started earlier. A mechanical engineer employed in the Austrian industry sector considers working in the EU important because of good living conditions and opportunities for training. He plans to stay in the company he is currently working for up to five years to complete masters and doctoral studies. As a disadvantage of living and working in Austria he mentioned a weak social life.

For a worker who works as a hygienist in a rehabilitation center in Germany, a job in the EU is important for her and her family's future, especially for her retirement. A respondent who works on the maintenance and cleaning in a clinic in Germany believes that working in the EU means a lot of sacrifices, especially for families and people he lives with, but that the working conditions are much better then in $\mathrm{BiH}$. A respondent working in the industry sector in Germany stated that his job in the EU was important for him to ensure the existence of his family. For a respondent employed in education sector in Germany as a trade intermediary, working in the EU is important for his existence. For a respondent employed in the industrial sector, working in Germany is currently the only way to provide a financial existence for himself and his family. An electrical engineer employed in a factory in Austria considers a job in the EU important for his family's existence.

A sales manager employed in the industrial sector was the only one to state that working in Germany was not essential or existential for him, but that he had decided to work there due to political turmoil and corruption, i.e. unregulated system in $\mathrm{BiH}$ and bad prospects for young people, and the return to the home country and building a career in it would not be a problem, as far as the financial side is concerned.

For a respondent employed in the IT sector in Germany, a job in the EU is important in terms of gaining new experience (different work environment, legal regulations, more diverse environment and challenges), and she believes that working conditions are better than in $\mathrm{BiH}$. A respondent employed in the IT sector in Germany stated that working in the EU brought him new experiences that he could not have gained otherwise and the opportunity to learn a new language, and that he had the opportunity to advance and build a career at his fingertips.

For a driver of a construction company in Croatia, working in the EU is the most important from the financial point of view, because he was unemployed for a long time and is currently earning income to support his family. For a worker in the financial sector in Austria, working in the EU is important because of the salary, as well as for another employee of a bank in Austria. For a worker working on cleaning facilities in Austria this is important for financial security and better security. 
For a respondent working as a human resources administrator in the Czech Republic (who previously worked in Germany), working in the EU is important because of working in a multicultural environment where more languages are used and because of greater chances for development, which is why the decision to leave the company in $\mathrm{BiH}$, where she had worked for five years and had a good job, prevailed.

An auxiliary worker in a factory in Sweden stated that working in the EU was important to him because, after being unemployed for a long time, he earned income to support his family. A driver employed in Slovenia considers working in the EU important because of a secure salary and health insurance, but as a disadvantage he states that he feels like a foreigner. Most of the other respondents shared positive impressions in relationships with residents. Especially, this is a case with respondents that have a higher level of education.

\subsection{Impact of the pandemic on employment and economic position}

The central research question was how the onset of the COVID-19 pandemic affected migrant workers, their employment, and the resolution of economic and social issues, as well as how migrants adapted to the situation. Retention, change of the type and manner of work and working conditions, or loss of work are certainly the most important consequences. According to the employment consequences, the studied migrants could be divided into four groups, which roughly represents a typology of possible consequences. The authors used the method of biographical-narrative analysis. Therefore, the numerical ratios in the presentation (Table 4) are for illustration only and individual experiences are shown later in the text.

Table 4: Typology of social-spatial consequences of pandemic COVID-19 to working relations.

\begin{tabular}{|l|l|l|l|}
\hline $\begin{array}{l}\text { Consequence/ } \\
\text { reaction type (what } \\
\text { happened to the job) }\end{array}$ & $\begin{array}{l}\text { Branch of activity } \\
\text { before pandemic }\end{array}$ & $\begin{array}{l}\text { Countries, where the } \\
\text { respondents work }\end{array}$ & $\begin{array}{l}\text { Education/ } \\
\text { Professional skills }\end{array}$ \\
\hline $\begin{array}{l}\text { lost job permanently } \\
(5)\end{array}$ & $\begin{array}{l}\text { personal services, } \\
\text { tourism, industry }\end{array}$ & D, SWE, CRO, IT, IT & $\begin{array}{l}\text { lower education 4), } \\
\text { professional (1) }\end{array}$ \\
\hline $\begin{array}{l}\text { fluctuation of } \\
\text { employment (4) }\end{array}$ & $\begin{array}{l}\text { industry, education } \\
\text { (2), transport }\end{array}$ & D, AT, SLO, D & $\begin{array}{l}\text { high (3), } \\
\text { professional (1) }\end{array}$ \\
\hline $\begin{array}{l}\text { from home, then } \\
\text { return (4) }\end{array}$ & $\begin{array}{l}\text { administration, } \\
\text { education, finance, } \\
\text { industry }\end{array}$ & CZ, SLO, AT, AT & high (4) \\
\hline remain working (9) & $\begin{array}{l}\text { industry, finance, IT } \\
\text { (2), tourism, traffic, } \\
\text { personal services (2) }\end{array}$ & $\begin{array}{l}\text { D, D, D, AT, AT, AT, } \\
\text { AT, SLO, SLO }\end{array}$ & $\begin{array}{l}\text { high (6), } \\
\text { professional (3) }\end{array}$ \\
\hline
\end{tabular}

Source: interviews (B. Ćudić), April 2020, N=22. 
In the first group are those who lost their jobs due to circumstances in labor market. 5 of the 22 workers surveyed, or about $22,7 \%$ of those surveyed, stated that after the borders were closed due to the pandemic in February 2020, they lost their jobs in the EU. All those who lost their jobs during that period have a secondary school degree and were employed in a job for which unskilled labor was required. This survey has showed that the corona virus had a negative impact on various sectors, as well as that the consequences of the pandemic were felt by all countries in which the respondents lived. The fact that they lost their jobs was stated in an interview by a worker who had worked in an electrical cabinets factory in Germany, an auxiliary worker who had been employed in a mechanical industry in Sweden, two workers who had worked in Italy and Austria on cleaning facilities (the worker in Italy had also worked in a catering industry), as well as a worker working as a driver at a construction site in Croatia. In economic terms, the pandemic, according to this survey, most often affected middle-aged workers because three of the five workers between the ages of 41 and 60 lost their jobs. One female worker between the ages of 25 and 40 and a female worker under the age of 25 also lost their jobs.

On the other hand, as the survey showed, the pandemic did not cause problems for highly qualified workers. Although it affected the way things were completed, the pandemic did not affect the employment and salaries of 17 respondents, including all 13 respondents with higher or faculty education. The other four are unskilled workers.

The second group are those who had to adapt to new circumstances on the work market by either changing the working conditions, location and in some cases even the employer. Fluctuation is probably a good mark that both the workers (i. e. migrants) and employers have adapted to new circumstances. For workers (migrants) the most important issue is to retain financial source, particularly for those who are in the country with families. There were four of them.

Third type is especially significant for »corona-period«: working from home. Since the most commonly used slogan was »stay home " (and this means to remain working, if possible, too), the tele-working became the first provisional solution for many branches as education, finance and assurances, administration, consulting and many others, including marketing, sale of different goods, development, research etc. »All online! « was a slogan, which »solved « many things. Among the respondents, there were 4 , who continued their job by jumping to online way of work. A human resources administrator (Czech Republic), a faculty employee (Slovenia), an electrical engineer working in industry (Austria) and a financial worker (Austria) worked from home in BiH.

The fourth group represent those who remain working, even though there were some adaptations in modus operandi. A bit surprisingly, there were 9 of all surveyed, or a bit less than half. This represents the working migrants as vulnerable, but flexible group. The work availability crucially depends on their skills and education.

As many as nine respondents stated that they worked in the same way as before the pandemic (same working hours, worked in their workplaces), but with increased 
protection measures, four worked from home, three did not go to work or worked with reduced scope of activities but regularly received full payment, while one respondent did not go to work for some time but received full payment, after which he worked as before the pandemic.

When it comes to people who worked as usual, there are two employees in the IT field (Germany and Austria), two workers working on maintaining cleanliness in hospitals (Germany), a sales manager (Austria), two drivers (Slovenia), a worker working in the field of finance (Austria) and a worker working in industry (Germany). Among those who did not work or worked on a reduced scale, but received a salary, there were two workers working in education (Germany) and one mechanical engineer (Austria). The driver who works in Slovenia did not work for a while because he was in Bosnia and Herzegovina and could not return to Slovenia, but his employer paid him a salary during that time, and later he continued to work.

The survey showed that the preservation of a job was influenced by a company or institution in which a worker was employed, so, for example, a driver who was employed in a construction company lost his job, while drivers who worked in companies which transport goods, as expected, worked constantly or with certain breaks. The situation is similar with workers who worked on cleaning and maintenance jobs, where those who did those jobs in houses or apartments lost their jobs, while those who did the same jobs in hospitals worked regularly.

Describing their experience during the pandemic, most of the workers, 7 out of 9 who worked at their workplace, stated that the employers were correct in fulfilling all their obligations and that they respected all prescribed protection measures, except for a driver employed in Slovenia who stated that he had to work more than Slovenian workers and a worker working in the field of finance in Austria who stated that he only had a mask of all protective equipment. Working in special conditions had in some cases positive effects when it comes to jobs performed by highly qualified workers. One respondent working from home said that this way of working had had an impact on higher productivity, but that direct communication had been lacking, while another stated that working from home had proved to work well, so it is considered that in normal circumstances workers, if they wish, work from home one or two days a week. In his answers, one respondent, who worked all the time, stated that his company had used the period of general standstill to develop new business models, and that he himself expected advancement. When it comes to expectations after the end of the pandemic, workers who lost their jobs believe that after the situation normalizes, they will start working again.

\subsection{The life experiences of migrants}

In some cases, a better job meant moving to another country within the EU. Thus, a worker who is employed in Germany in a factory that manufactures electrical cabinets found that job after having worked in Slovenia on cutting iron. The driver employed 
in Slovenia got the job through an employment agency, but after a short time he moved to work in another company that offered him better working conditions. A driver who got a job in Croatia through an advertisement, based on a recommendation, got a job in Slovenia. A worker who found a job in the journalism, communications and political science sector in Germany through an advertisement, found a new, better job based on an advertisement from Amazon in the Czech Republic, where she works as a senior human resources administrator for the German market. A mechanical engineer working in Germany first worked in a hotel, and two years later he managed to get a job in the profession - first in the company "Bosch", and then in a secondary school.

The survey in which the workers described their experiences with the work in the $\mathrm{EU}$ also showed that workers from $\mathrm{BiH}$ employed in EU countries are generally satisfied with employers, working conditions and earnings.

20 respondents stated that they had a completely positive experience with working in the EU, while two respondents made complaints about employers and working conditions. Respondents stated the following as positive sides of working in the EU: good working conditions, good salaries, paid overtime work, a strong union, a possibility of advancement, an organized system, fair employers with whom they can communicate and who fulfil what is written in the employment contract, regular settlement of obligations to workers, benefits, bonuses and salary increases, security in the labor market.

The driver employed in Slovenia was not satisfied with the working conditions, pointing out that he had a permanent employment contract, but that it was not respected in all cases by the employer and that the workers had to fight for good working conditions and that it took a lot of time, that he worked more than his colleagues who are Slovenians, and he also stated that his employer had not provided him with a meal allowance, but that he had done it himself. A respondent who worked in the industry sector in Sweden stated that he had been satisfied with the business approach and salary, which had been in accordance with the agreement and the contract, but he emphasized that he had to fight for all rights himself and that there had been no room for mistakes with the employer.

The survey showed that most respondents, regardless of their profession or education, have a need or desire to learn a language of a country in which they work, and only one respondent does not know any foreign language. As many as 19 of 22 of them communicate business and privately in a language of a country in which they currently work, while two communicate only in English, and one only in Serbian. A driver working in Slovenia communicates only in Serbian (Serbian is spoken by his employer and can communicate when necessary), while a worker working in education in Germany as a trade intermediary and a worker working in Sweden as an auxiliary worker in industry communicate in English.

When it comes to people who worked in two EU countries, a worker who worked in Germany in the field of communications and then got a job in the Czech Republic as a human resources manager speaks German and English, but not Czech, while a 
worker who worked in Italy and Germany in the catering sector speaks both Italian and German.

It is interesting that business communication in English is mandatory for seven workers in Germany and Austria (workers in the IT and financial sector, engineers, sales manager, sales broker), and six of them also use the language of the country (German) in which they work. A researcher working at a faculty in Slovenia communicates business in English and Slovenian.

A respondent who first worked in a hotel in Germany and then got a job in a secondary school, first used English, and then was obliged to learn German. Only English was used at the beginning of his work in Germany by a respondent employed in cleaning and maintaining a clinic, but then he learned the German language he uses at work. A driver who works in Slovenia initially communicated in Serbian, but after a while he learned Slovenian language.

When it comes to housing conditions during work in the EU, it turned out that the situation was more or less similar for all workers, regardless of what and in which country they worked. Thus, more than half of the respondents - 15 of them - live as tenants. For five respondents, the apartment is provided by their employers, while two respondents had their own apartments. When it comes to workers whose apartment is provided by an employer, it is a driver of a construction company in Croatia, a worker who works in a factory in Germany, two drivers of transport companies in Slovenia and a hygienist who works in a hospital in Germany. A worker who has been working in the IT sector in Germany for 1.5 years and a worker who has 15 years of work experience in Germany and Italy, and who bought the apartment in Italy while living in Germany as a tenant, have their own apartments.

\section{CONCLUSIONS}

In the study on labor migration from Bosnia and Herzegovina to the EU, we paid special attention to the effects on migrants' work and life after the COVID-19 pandemic: how these rapid changes affected their employment and economic and social issues, as well as how migrants adapted to the resulting situation. Due to limited time and communication opportunities, 22 interviews were conducted, which were later interpreted according to a biographical-narrative approach. The general impression is that labor migrants have proven to be a flexible group and have largely retained work and the associated economic benefits. The general impression is that the pandemic did not endanger their jobs more than employed locals in the same environments. Problems due to measures of social distancing and closing of borders, and in some cases repatriation, also mostly took place without major complications. It has also been shown that migrants with higher education and / or qualifications are socially safer than those with lower education, which is also due to greater flexibility of migrants 
on the one hand and employers' awareness of the importance of foreign workers. The latter can probably be attributed to the relatively high level of trust in $\mathrm{BiH}$ workers. The meaning of integration of immigrants into societies is therefore important issue; interesting, that more and more countries built relatively common, if not unique model, how to incorporate foreign workers into society (Lukić, Tomašević, 2020, pp. 145-146). COVID-19 therefore had an impact on the way and location of work, but in the short term it did not significantly jeopardize jobs, nor did it have a stronger impact on the allegedly weaker group of foreign workers in the EU.

Opomba: Članek je nastal v okviru delovanja dveh programskih skupin, in sicer Programske skupine P6-0372 in P6-0229.

\section{References}

Bertić, I. (ed.), 1987. Veliki geografski atlas Jugoslavije. Zagreb: Sveučilišna naklada Liber.

Eurostat, 2020. First permits by reason, length of validity, and citizenship. URL: https://ec.europa.eu/eurostat/web/products-datasets/product?code=migr_resfirst (accessed 29.10.2020).

Hazemali, D., 2017. The Battle of Galicia: the disintegration of the Austro-Hungarian land forces on the eastern front in the first world war, with special emphasis on the role of the Graz's III corps and Slovenian soldiers. Studia Historica Slovenica 17, 1, Maribor, pp. 161-196.

Ilc Klun, M., 2014. Teoretična in terminološka izhodišča izseljenstva ter poznavanje tematike izseljenstva med slovenskimi učenci in dijaki. Dela, 41, str. 165-181.

Ilc Klun, M., 2017. Biografsko-narativni metodološki pristop za poučevanje in razumevanje vsebin slovenskega izseljenstva. Dela, 48, str. 61-76. DOI: 10.4312/ dela.48.2.61-76.

Izdana dovoljenja za prebivanje januar-december. 2019. URL: https://www.gov.si/podrocja/drzava-in-druzba/priseljevanje-v-slovenijo/ (accessed 14.07.2020).

Klemenčič, M., 1987. Ameriški Slovenci in NOB v Jugoslaviji. Maribor: Založba Obzorja.

Klemenčič, M., 2000. Prostovoljne in prisilne migracije kot orodje spreminjanja etnične strukture na območju držav naslednic nekdanje Jugoslavije. Razprave in gradivo: revija za narodnostna vprašanja, 36/37, str. 145-172.

Klemenčič, M., 2013. Bosnians, Bosniaks (Muslim), and Bosniak Americans, 1940-present. In: Barkan, E. R (ed.). Immigrants in American history: arrival, adaptation, and integration. Santa Barbara, Denver, Oxford: ABC-CLIO, pp. 767-773.

Klemenčič, M., Žagar, M., 2004. The former Yugoslavia’s diverse peoples: a reference sourcebook. Santa Barbara: ABC-CLIO. 
Komac, M. (ed.), 2007. Priseljenci. Študije o priseljevanju in vključevanju v slovensko družbo. Ljubljana: Inštitut za narodnostna vprašanja.

Lazanin, S. 2017. Životna priča jednog iseljenika kao izvor za proučavanje migracija, Migracijske i etničke teme, 33, 2, pp. 221-229.

Lukić, V., Tomašević, A., 2020. Immigrant integration regimes in Europe: Incorporating the Western Balkan countries. Acta geographica Slovenica/Geografski zbornik, 60, 1, pp. 143-154. DOI: 10.3986/AGS.7286.

Mežnarić, S., 1986. Bosanci. A kuda idu Slovenci nedeljom. Ljubljana: Založba Krt.

Pašalič, S., Lalić, N., 2020. Demografski indikatori i demografska (GIS) analiza. Opštine, gradovi, kantoni, Republika Srpska, Federacija BiH, Distrikt Brčko, Bosna i Hercegovina. Bijeljina: Pedagoški fakultet.

Peračković, K., Rihtar, S., 2016. Materijalizam kao društvena vrijednost I poticaj namjerama iseljavanja iz Hrvatske. Migracijske i etničke teme, 32, 3, Zagreb, pp. 295-317.

Pirjevec, J., 2003. Jugoslovanske vojne: 1991-2001. Cankarjeva založba, Ljubljana.

Rančić, M. (ed.), 1990. Pogledi na migracije stanovništva Jugoslavije. Beograd: Centar za demografska istraživanja, Univerzitet u Beogradu.

Rogelj, B., 2017. Violent borders: refugees and the right to move. Dela, 48, pp. 129132, Ljubljana.

Shrivastava, S., Shrivastava, P., 2020. Ensuring safe repatriation of the citizens amidst the threat of Corona Virus Disease 2019 Pandemic. Cukurova Medical Journal, 45, pp. 767-768. DOI: 10.17826/cumj.727470.

Statistics Canada, 2020. 2011 National Household Survey: Data tables. URL: https:// www12.statcan.gc.ca/nhs-enm/2011/dp-pd/dt-td/Rp-eng.cfm?LANG=E\&APAT$\mathrm{H}=3 \& \mathrm{DETAIL}=0 \& \mathrm{DIM}=0 \& \mathrm{FL}=\mathrm{A} \& \mathrm{FREE}=0 \& \mathrm{GC}=0 \& \mathrm{GID}=0 \& \mathrm{GK}=0 \& \mathrm{GRP}=1$ \&$\mathrm{PID}=105396 \& \mathrm{PRID}=0 \& \mathrm{PTYPE}=105277 \& \mathrm{~S}=0 \&$ SHOWALL $=0 \& S U B=0 \&$ Tempo$\mathrm{ral}=2013 \& \mathrm{THEME}=95 \& \mathrm{VID}=0 \& \mathrm{VNAMEE}=\& \mathrm{VNAMEF}=($ accessed 29.10 .2020$)$.

Verska, jezikovna in narodna sestava prebivalstva Slovenije. Popisi 1921-2002, 2003: Posebne publikacije, št. 2. Ljubljana: Statistični urad Republike Slovenije.

Winkler, W., 1931. Statistisches Handbuch der Europaeischen Nationalitaeten. Wien, Leipzig: Wilhelm Braumueller, Universitaets-Verlagsbuchhandlung.

Zupančič, J., 2015. Geografija Balkana in njegovega obrobja. Ljubljana: Znanstvena založba FF.

Zupančič, J., 2004. Ethnic structure of Slovenia and Slovenes in the neighbour countries. In: Slovenia: A geographic overview. Ljubljana: Založba ZRC, pp. 87-92. 


\section{COVID-19 IN MEDNARODNE DELOVNE MIGRACIJE IZ BOSNE IN HERCEGOVINE V EU}

\section{Povzetek}

Prispevek obravnava vprašanje sodobnih delovnih migracij iz Bosne in Hercegovine v Slovenijo in države Srednje Evrope, in sicer specifično za čas razglašene pandemije COVID-19. Predvidevali smo, da so dokaj nenadna zapora meja, vračanje državljanov $\mathrm{v}$ domovino, družbeno distanciranje in druge okoliščine, povezane $\mathrm{z}$ ukrepi držav, $\mathrm{v}$ katerih so delovni migranti delali in bivali, posegli v delovni in življenjski ritem vseh, tujih delavcev pa še posebej. Osrednje raziskovalno vprašanje je bilo, kako je nastop pandemije COVID-19 vplival na delovne migrante, njihovo zaposlenost in reševanje ekonomsko-socialnih vprašanj ter tudi, kako so se migranti prilagajali na nastale razmere. Da bi ugotovili učinke pandemije na status in način dela ter položaj migrantov, je bila izvedena kratka terenska raziskava med udeleženci teh migracij: 22 intervjujev. Zaradi nizkega števila in drugih posebnosti vzorca smo se odločili za biografsko-narativno metodo, po kateri je spremljanje zanimivih življenjskih sekvenc migrantov podlaga za ilustracijo razmer, v katerih so se migranti znašli. Tega ne moremo posplošiti. Predvidevali smo, da so se delovni migranti v teh okoliščinah znašli kot posebej ranljiva skupina prebivalstva. S študijo primera smo dokazali, da to ne drži povsem. Udeleženi migranti so bili iz entitete BiH Republike Srbske, v vzorcu so rahlo prevladovali moški in višje- ter visoko izobraženi oziroma ustrezno kvalificirani. Po drugi strani pa so delovne migracije iz Bosne in Hercegovine proti državam Srednje, Zahodne in Severne Evrope kontinuiran proces zadnjega stoletja in je vsaj selitvene tokove treba vzeti kot določeno družbeno konstanto, na katere smer, številčnost in značaj v veliki meri vplivajo ureditve trga dela v posameznih članicah EU, obdobno pa dobijo prevladujoč vpliv tudi specifične družbene razmere. Tak vpliv predstavlja tudi pandemija COVID-19.

Poleg uvoda in metodoloških opomb je v prispevku prikazana zgodovina migracij iz $\mathrm{BiH}$ v novejši moderni dobi, to je nekako od srede 19. stoletja dalje vse do danes. Ta časovna zamejitev predstavlja čas, v katerem je prostorski okvir $\mathrm{BiH}$ skoraj enak, spreminjale pa so se družbene in politične razmere, ki so teritorij $\mathrm{BiH}$ postavljale v državne tvorbe Osmanskega imperija, nato habsburške Avstro-Ogrske, kraljevine Jugoslavije, socialistične jugoslovanske federacije in po njenem razkroju v seriji vojn med 1991 in 2001 ustanovitev $\mathrm{BiH}$ (1992). Posebej smo se osredotočili na obdobje po 1995, ki je pomemben mejnik predvsem zaradi daytonskega mirovnega sporazuma, ki je končal štiriletno državljansko vojno, a oblikoval administrativno dokaj zapleteno delujočo državo pod mednarodnim nadzorom. Te faze političnega razvoja so zaradi kontekstov, ki so jih ustvarjale, pomembno vplivale na migracijske tokove iz Bosne in Hercegovine ter znotraj nje. Značilno namreč je, da so se migracije povečevale tako $\mathrm{v}$ času političnih kriz in vojaških konfliktov (kjer je bila glavna oblika in razlog selitev begunstvo) kot v časih ekonomskega razvoja. Medtem ko so krize navadno dokaj 
očiten razlog in okoliščina selitve, so selitve $\mathrm{v}$ času blagostanja $\mathrm{v}$ prepletu motivov bolj zapletene. Ključno pa je, da je mogoče vse, celo krizne migracije v določeni meri, postaviti na skupni imenovalec ekonomskih oziroma materialnih okvirov. Ti pa nikakor niso edini, a so skoraj vselej prisotni.

Nastop COVID-19 predstavlja določen stres, ki v večji meri prizadene migrante. Te navadno percipiramo kot ranljivo družbeno skupino, domnevajoč da bodo delo in $s$ tem povezane materialne in druge koristi izgubili prej kot primerljiva skupina domačih delavcev. Vendar se je izkazalo, da so motivi za delo v tujini le izhodiščno ekonomski, motivov pa je precej več.

Splošen vtis je, da so se delovni migranti izkazali kot fleksibilna skupina in so večinoma zadržali delo in s tem povezane ekonomske koristi. Splošen vtis je, da zaradi pandemije njihova delovna mesta niso bila bolj ogrožena kot pri zaposlenih domačinih v istih okoljih. Tudi težave zaradi ukrepov družbenega distanciranja ter zapiranja meja ter $\mathrm{v}$ nekaterih primerih vračanja $\mathrm{v}$ domovino so večinoma potekala brez večjih zapletov. Izkazalo se je tudi, da so migranti z višjo izobrazbo in/ali kvalifikacijami socialno bolj varni kot oni $z$ nižjo izobrazbo, kar gre tudi na račun večje prilagodljivosti migrantov na eni ter zavedanja delodajalcev o pomenu zaposlenih tujih delavcev. Slednje gre verjetno pripisati sorazmerno visokemu zaupanju v delavce iz $\mathrm{BiH}$. COVID-19 je torej s svojimi posledicami sicer vplival na način in lokacijo dela, vendar pa kratkoročno ni bistveno ogrozil delovnih mest niti ni vplival močneje na domnevno šibkejšo skupino tujih delavcev v EU. 